\title{
Evening Primrose (Oenothera biennis L.): Morphology and Reproductive Biology
}

\author{
Usha Thakur $^{1 *}$, Bhupender Dutt ${ }^{1}$, S. S. Sharma ${ }^{1}$, \\ Kulwant Rai Sharma ${ }^{1}$ and Nisha Thakur ${ }^{2}$
}

\author{
${ }^{1}$ Department of Forest Products, College of Forestry, Dr. Y. S. Parmar University of \\ Horticulture and Forestry, Nauni-Solan, Himachal Pradesh, India, 173230 \\ ${ }^{2}$ ICAR-IARI, Regional Station, Katrain, Himachal Pradesh, 175129, India
}

*Corresponding author

\begin{tabular}{|l|}
\hline Ke y w o r d s \\
Evening primrose, \\
Oenothera biennis \\
L., Pollination, Self \\
and Cross \\
pollination
\end{tabular}

A B S T R A C T
Oenothera biennis L., commonly known as Evening Primrose as flowers open in the evening. Inflorescence is racemose (spike) and flowering continues for about 3 months. Circular floral nectary of translucent colour are present at the point of attachment of petals and hypanthium. Pollen are triporate, of variable sizes held together by viscin threads. Sepals colour change from green to yellowish green, act as indicator of anther dehiscene in the morning in closed conditions and anthesis in the evening. Flower is protandrous. The stigmatic lobes remain compact above the anthers till anthesis. Stigma radiates and turns receptive at the time of anthesis on the same day in the evening and remains so till next day afternoon. Anthesis completes with in 15 minutes i.e. from closed bud to full bloom. The species is both self and cross pollinated but mostly cross pollinated and is carried out by insects during both day and night. It is both cross as well as self-compatible.

\section{Introduction}

Oenothera biennis L. (family Onagraceae), a native north American species, commonly known as evening primrose as the flowers open in the evening, king's cureall and night willow herb etc. Evening primrose is important because of its seeds oil i.e. evening primrose oil (EPO) (Hall et al., 1988), which characterized by its content of gamma linolenic acid (7-10\%) (GLA), the precursor of prostaglandin E1 and its derivatives (Hudson, 1984 and Yunusova et al., 2007). The oil is used in preparation of medicines, nutrients, health products and cosmetics (Deng et al., 2001). It is used for a wide range of conditions including premenstrual syndrome (PMS), mastalgia, atopic eczema, rheumatoid 
arthritis (Riaz et al., 2009; Ratnayake et al., 1989; Yunusova et al., 2007; Ghasemnezhad, 2007; Anonymous, 2009; Horrobin, 1992). In recent years there has been an increased interest in plants that produce GLA. EPO is preferred to other source of GLA because it is most effective among others. Its simple composition, high level of linoleic acid that may facilitate the absorption of GLA, having most biologically active form of GLA (enotherol), easy to produce, high cost of GLA extraction from fungus etc. make it preferable than others (Hudson, 1984; Ghasemnezhad, 2007; Pesche et al., 2007; Riaz et al., 2009). It is available as a nutritional supplement in over 30 countries and is grown commercially in at least 15 countries. It has been reported that during the year 2008, EPO was the $20^{\text {th }}$ top selling botanical dietary supplement (Cavaliere et al., 2009; Gunstone, 1992). Due to increasing scope of the species in various medicinal and pharmaceutical industries, there is need not only to grow this crop on a large scale but also for its improvement to make it economically acceptable to the growers. Therefore, the present study was undertaken to understand its morphological features for correct identification of the plant, reproductive biology to determine the degree of variability expected in a population and understanding of its breeding behaviour which helps the breeder in formulating the hybridization programme and genetic improvement.

\section{Materials and Methods}

Morphological and pollination studies were carried out on field grown plants in Dr. Y. S. Parmar University of Horticulture \& Forestry, Nauni-Solan campus. All morphological parameters data were collected at full inflorescence stage. Cauline leaves were measured at full inflorescence stage, while radical leaves were measured just before appearance of cauline leaves. Pollen dehiscence stage was determined by opening the closed bud manually at different time interval. Stigma receptivity was determined by placing fresh pollen on stigma and periodically observing for pollen germination under a microscope. Pollen viability was studied by hanging-drop method using $10 \%$ sucrose solution, micronutrients and fresh pollen treated with hexane to convert it into dust form. Controlled pollination was done at stigma-receptive stage using fresh pollen. In bagging and controlled selfing, buds that were about to open were covered with butter paper bags in such a way that one flower bloom in one paper bag. While in the former the buds/flowers were left as such till the flower turns the colour to dark orange i.e. next day evening or flower detach from the ovary. In the later i.e. controlled selfing, after floweropening, the bag was removed, stigma was hand-pollinated with pollen from the same flower or flower from same plant and rebagged. In open cross and controlled cross, buds which are about to turn or turns greenish yellow in colour in the morning were carefully emasculated (in the morning). In the former such buds were left open, while in the later the emasculated buds were bagged and at the time of anthesis were hand-pollinated with pollen from other plants and rebagged. In open pollination, unopened buds were tagged and left for natural pollination without any artificial intervention. Detachment of flower from its ovary, increase in ovary size and its transformation into capsular fruit were taken as signs of fruit set. Seed germination of all the pollination treatments were carried out in the germinator at $25 \pm 5^{\circ} \mathrm{C}$.

\section{Results and Discussion}

Plants of Oenothera biennis are erect, annual herb (Fig. 1). The initial phase of growth commencing from nursery up to the emergence of main shoot was characterized by the presence of large rosette, radical leaves. The main shoot that becomes hard at the later 
stages, emerged producing cauline leaves, flowers, capsules and seeds. It flowers and bears seed only once in a life time. Qualitative and quantitative data on morphological features of the species were given in Table 1 \& 2. Earlier Pullaiah (2006) and Hall et al., (1988) in O. biennis and Naik et al., (1999) in O. lamarckiana also reported the description of plant.

Floral bud, after appearance, took about 104 days for complete capsule dehiscence. Initially the bud showed slow progression in growth reaching its maximum in about 24 days after bud appearance when flower blooms (Table 4). The flowering occurs from $3^{\text {rd }}$ week of July to $2^{\text {nd }}$ week of October $(75 \%$ of flowering completes) and fruits harvested from $2^{\text {nd }}$ week of October to last week of December (Table 3 ). The time of anthesis is evening. The flower remains open till next morning, then wilt by forenoon and evening and fall by next day or day after tomorrow. Similar finding i.e. the flowers open at dusk and wilt in the following morning was reported by Hall et al., (1988). The colour of flower at the full bloom stage and after that when flower wilt \& dehisce, changes from yellow to orange (Fig. 1). Fixed number of flowers open in the evening. In one spike 3-5 buds bloom in the evening in one day and whole anthesis completes within 15 minutes. Anthers mature and dehisce, 24 days after flower bud appearance, on the day of anthesis, in the morning from 10:00 a.m. up to 12:00 noon. Pollen were shed while the petals were convolute in the bud i.e. flower is protandrous (Table 5). Hall et al., (1988), also revealed that the pollen is shed while the petals are convolute in the bud. The flowers which is about to open in the evening changes their sepals colour from green to yellowish green and it act as indicator of anther dehiscence and anthesis in the evening. The pollen is held together by viscin threads which makes it a web like structure. When the pollen is shed in the closed condition it does not touch the stigma as stigma is compact vertically and above the range of pollen and not receptive at this stage (Fig. 1). Anthesis occurs on the same day in the evening i.e. 7-9 hrs after anther dehiscence and flower remains open till next day afternoon i.e. 25 days after floral bud initiation. At the anthesis stigma radiates and turns receptive and continues so till next day early noon (Table 5).

The maximum pollen germinability was observed to be 50 per cent at anther dehiscence stage (Fig. 1). When stigma radiates, pollen touches only lower part of stigma. Complete pollination is assisted by insect visitation leading to cross pollination as pollen are sticky in nature and sticks to insects body. Availability of viable pollen over a longer period helps protandrous flowers in cross-pollination. The vectors are rewarded by pollen and nectar. Circular ring shaped translucent floral nectary was observed at the point of attachment of petal and hypanthium. Different insect vectors, bumble bee (Bombus sp.), honeybee (Apis sp.) were seen visiting flowers in the day time and hawk moth (Hyles spp.) in the night (Table 6 and Fig. 1). They are responsible for maximum pollination. Immel (2003) believed, flower to be pollinated by night visiting hawk moths, which feed on their nectar. Immel (2003) reported that humming birds (Archilochus spp.) visit the flower to obtain nectar and to eat insects, which was not seen. Another feature that attract the insects in the night is the bright colour which is visible in night by nocturnal insects. This encourages the insect to enter the flower for effective pollination. This is a common feature of flowers of Oenothera sp. Dement and Raven (1974) reported that $O$. hookeri spp. Venusta has nectar guides visible by their contrasting UV patterns to insects but not humans.

Except selfing (bagging), all the treatment are at par with each other for fruit set (\%) and other parameters. 
Table.1 Qualitative morphological features of $O$. biennis

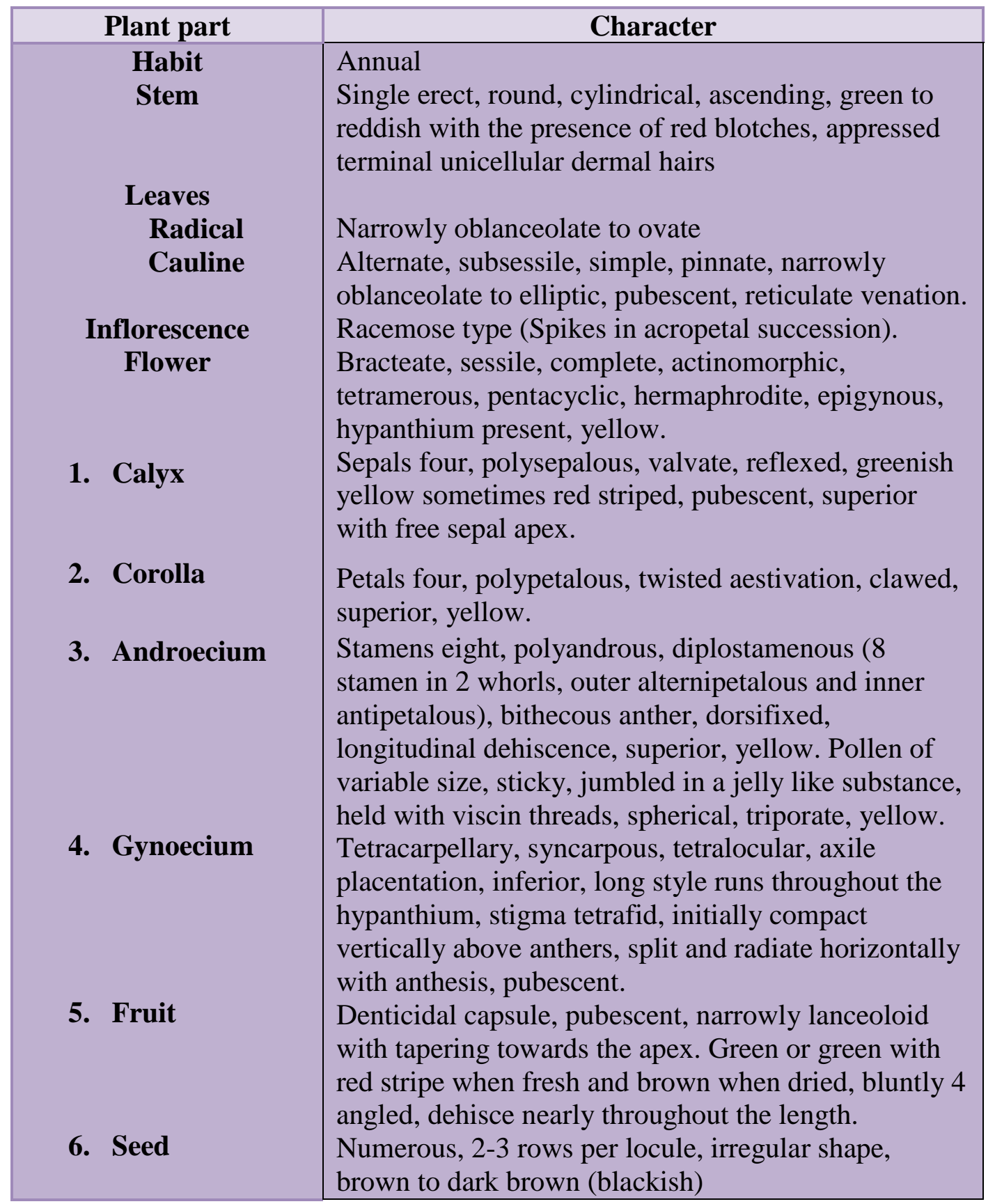


Table.2 Quantitative morphological parameters of $O$. biennis

\begin{tabular}{|c|c|}
\hline Parameter & Dimension/number \\
\hline Plant height & $160 \pm 10 \mathrm{~cm}$ \\
\hline $\begin{array}{l}\text { Root } \\
\text { Number (main roots) } \\
\text { Length (longest root) }\end{array}$ & $\begin{array}{c}15 \pm 4 \\
39 \pm 7.5 \mathrm{~cm}\end{array}$ \\
\hline $\begin{array}{l}\text { Leaves } \\
\text { Number of radical leaves } \\
\text { Number of cauline leaves } \\
\text { Size of radical leaves } \\
\text { Size of cauline leaves }\end{array}$ & $\begin{array}{c}22 \pm 5 \\
186 \pm 50 \\
20 \pm 10 \mathrm{~cm} \times 5.5 \pm 1.0 \mathrm{~cm} \\
15 \pm 10 \mathrm{~cm} \times 4.4 \pm 2.0 \mathrm{~cm}\end{array}$ \\
\hline Number of flowering shoot per plant & $12 \pm 5 \mathrm{~cm}$ \\
\hline Length of inflorescence & $35 \pm 5 \mathrm{~cm}$ \\
\hline Flower & $7.5 \pm 0.8 \mathrm{~cm} \times 5.0 \pm 0.4 \mathrm{~cm}$ \\
\hline Bracts & $3 \pm 2.1 \mathrm{~cm} \times 1.3 \pm 0.6 \mathrm{~cm}$ \\
\hline $\begin{array}{l}\text { Calyx } \\
\text { Number of sepals } \\
\text { Length }\end{array}$ & $\begin{array}{c}4 \\
2.9 \pm 0.5 \mathrm{~cm} \mathrm{x} 0.4 \pm 1 \mathrm{~cm}\end{array}$ \\
\hline $\begin{array}{l}\text { Corolla } \\
\text { Number of petals } \\
\text { Length }\end{array}$ & $\begin{array}{c}4 \\
2.5 \pm 0.5 \mathrm{~cm} \times 2.5 \pm 0.7 \mathrm{~cm}\end{array}$ \\
\hline $\begin{array}{l}\text { Androecium } \\
\text { Number of stamens } \\
\text { Length of stamens } \\
\text { Anther length } \\
\end{array}$ & $\begin{array}{c}8 \\
1.8 \pm 0.3 \mathrm{~cm} \\
0.6 \pm 0.3 \mathrm{~cm}\end{array}$ \\
\hline $\begin{array}{l}\text { Pollen } \\
\text { Size }\end{array}$ & $2(0.08 \mathrm{~mm}$ and $0.06 \mathrm{~mm})$ \\
\hline $\begin{array}{l}\text { Gynoecium } \\
\text { Number of carpel } \\
\text { Length of ovary } \\
\text { Ovary diameter } \\
\text { Length of stigma }\end{array}$ & $\begin{array}{c}4 \\
1.0 \pm 0.2 \mathrm{~cm} \\
0.15 \pm 0.2 \mathrm{~mm} \\
0.8 \pm 0.2 \mathrm{~cm}\end{array}$ \\
\hline $\begin{array}{l}\text { Fruit (capsule) } \\
\text { Length } \\
\text { Weight (green) }\end{array}$ & $\begin{array}{l}3.0 \pm 0.5 \mathrm{~cm} \\
0.8 \pm 0.13 \mathrm{~g}\end{array}$ \\
\hline $\begin{array}{l}\text { Seed } \\
\text { Length } \\
1000 \text { seed weight }\end{array}$ & $\begin{array}{c}1.6 \pm 0.4 \mathrm{~mm} \times 0.9 \pm 0.2 \mathrm{~mm} \\
0.347 \pm 0.004 \mathrm{~g}\end{array}$ \\
\hline
\end{tabular}


Table.3 Corresponding sequence of events in development of $O$. biennis

\begin{tabular}{|c|l|c|}
\hline \multicolumn{1}{|c|}{ Event } & \multicolumn{1}{|c|}{ Date } & Time Taken \\
\hline Sowing of seeds & $12^{\text {th }}$ March & 6 days \\
\hline Seed germination & $18^{\text {th }}$ March & 63 days \\
\hline Transplanting & $20^{\text {th }}$ May & 61 days \\
\hline $\mathbf{1}^{\text {st }}$ flowering & $20^{\text {th }}$ May & 83 days \\
\hline Flowering period & $\begin{array}{l}20^{\text {th }} \text { July }-10^{\text {th }} \text { October } \\
\left(3^{\text {rd }} \text { week July- } 2^{\text {nd }} \text { week of Oct. }\right)\end{array}$ & $81-82$ days \\
\hline $\begin{array}{c}\text { Capsule ripening } \\
\text { (Harvesting) }\end{array}$ & $\begin{array}{l}8^{\text {th }} \text { October }-28^{\text {th }} \text { December } \\
\left(2^{\text {nd }} \text { week of Oct.-last week of Dec }\right)\end{array}$ \\
\hline Total growth period & $12^{\text {th }}$ March $-28^{\text {th }}$ December & 295 days \\
\hline
\end{tabular}

Table.4 Sequence of events starting from the bud initiation to seed dispersal in O. biennis

\begin{tabular}{|c|c|}
\hline Number of days & Events \\
\hline $\mathbf{0 - 2}$ Days & Floral buds started appearing with four calyx lobes closely held together \\
\hline $\mathbf{2}^{\text {nd }}-\mathbf{2 5}^{\text {th }}$ day & Bud grew in size with increase in size of ovary \\
\hline $\mathbf{2 4}^{\text {th }}$ day morning & Colour of bud changed from green to yellowish green \\
\hline $\mathbf{2 4}^{\text {th }}$ day morning & Anther below the stigma start dehiscing with stigmatic lobes compact vertically \\
\hline $\mathbf{2 4}^{\text {th }}$ evening & Anthesis occur with spliting or radiating stigmatic lobes \\
\hline $\mathbf{2 5}^{\text {th }}$ morning & Flower remain open \\
\hline $\mathbf{2 5}^{\text {th }}$ evening & Flower starts to wilt with the colour changing from yellow to orange \\
\hline $\mathbf{2 6}^{\text {th }}$ and $\mathbf{2 7}$ & Flower with its floral parts detach from the ovary \\
\hline $\mathbf{2 7}_{\mathbf{1 0 3}} \mathbf{1 0 y}$ & Size of capsule increases \\
\hline $\mathbf{1 0 4}^{\text {th }}$ day & Capsule tip starts opening and start dehiscing \\
\hline
\end{tabular}

* Number of days from bud initiation

Table.5 Corresponding sequence of events in development of pollen and stigma receptivity

\begin{tabular}{|c|c|c|c|c|}
\hline \multirow{2}{*}{$\begin{array}{l}\text { No. of days } \\
\text { since bud } \\
\text { initiation }\end{array}$} & \multirow[t]{2}{*}{ Time } & \multirow[t]{2}{*}{ Floral stage } & \multicolumn{2}{|c|}{ Maturation stage } \\
\hline & & & Anther & Stigma \\
\hline $24^{\text {th }}$ day & $\begin{array}{c}\text { 10:00 am-12:00 } \\
\text { noon }\end{array}$ & $\begin{array}{l}\text { Bud closed, greenish yellow in } \\
\text { colour }\end{array}$ & Anther dehisce & $\begin{array}{l}\text { Stigma compact } \\
\text { vertically, above anthers } \\
\text { and not receptive }\end{array}$ \\
\hline $24^{\text {th }}$ day & $6: 00 \mathrm{pm}-7: 00 \mathrm{pm}$ & $\begin{array}{l}\text { Separation in sepals and petals, } \\
\text { anthesis starts, Flower yellow in } \\
\text { colour }\end{array}$ & $\begin{array}{l}\text { Anthers } \\
\text { dehisced }\end{array}$ & $\begin{array}{l}\text { Stigma splits and radiates, } \\
\text { stigma turns receptive }\end{array}$ \\
\hline $25^{\text {th }}$ day & $\begin{array}{l}\text { Morning till } \\
\text { 12:00 noon }\end{array}$ & Flower remain open & $\begin{array}{l}\text { Anthers } \\
\text { shrivelled }\end{array}$ & Stigma receptive \\
\hline $25^{\text {th }}$ day & Evening & $\begin{array}{l}\text { Flower changes colour to dark } \\
\text { orange colour and whole flower wilt }\end{array}$ & & $\begin{array}{l}\text { Stigma lobes loose } \\
\text { receptivity }\end{array}$ \\
\hline 26- $27^{\text {th }}$ day & & $\begin{array}{l}\text { Flower wither and detach from } \\
\text { ovary }\end{array}$ & & \\
\hline
\end{tabular}


Table.6 Floral characters of $O$. biennis

\begin{tabular}{|c|c|}
\hline Floral characters & Observations \\
\hline Flowering period & Mid July to Mid October \\
\hline Pollination & $\begin{array}{l}\text { Either by contact to some extent } \\
\text { (selfing) or by insects (entomophily) }\end{array}$ \\
\hline Odour & Absent \\
\hline Nectar & Present (translucent and circular ring) \\
\hline Flower opening time & Dusk \\
\hline Anther dehiscence time & 10:00 am - 12:00 noon \\
\hline Anther dehiscence mode & Longitudinal \\
\hline Type of dichogamy & Protandrous \\
\hline Pollen shape & Spherical, triporate \\
\hline Stigma type & Tetrafid above the anther level \\
\hline Days taken for capsule maturity & $80-82$ days after pollination \\
\hline
\end{tabular}

Table.7 Effect of different pollination methods in O. biennis

\begin{tabular}{|c|c|c|c|c|c|c|c|c|}
\hline $\begin{array}{l}\text { Parameters } \\
\text { Treatment }\end{array}$ & $\begin{array}{c}\text { Fruit set } \\
(\%)\end{array}$ & $\begin{array}{l}\text { Capsule } \\
\text { length } \\
\text { (cm) }\end{array}$ & $\begin{array}{l}\text { Capsule } \\
\text { weight } \\
\text { (g) }\end{array}$ & $\begin{array}{l}\text { Seed yield } \\
\text { /capsule } \\
\text { (g) }\end{array}$ & $\begin{array}{l}\text { Seed yield } \\
\text { /plant } \\
\text { (g) }\end{array}$ & $\begin{array}{c}\text { No of } \\
\text { Seeds } \\
\text { /capsule }\end{array}$ & $\begin{array}{l}\text { No of } \\
\text { seeds } \\
\text { /plant }\end{array}$ & $\begin{array}{c}\text { Germination } \\
(\%)\end{array}$ \\
\hline $\begin{array}{c}\text { Open } \\
\text { pollination }\end{array}$ & $\begin{array}{c}95.00 \\
(80.78)^{*}\end{array}$ & 2.96 & 0.26 & 0.13 & 39.52 & $\begin{array}{c}325.00 \\
(2.51)^{* *}\end{array}$ & $\begin{array}{l}98730.00 \\
(4.99)^{* * *}\end{array}$ & $\begin{array}{c}95.00 \\
(9.75)^{* * *}\end{array}$ \\
\hline $\begin{array}{c}\text { Selfing } \\
\text { (bagging) }\end{array}$ & $\begin{array}{c}62.50 \\
(52.28)\end{array}$ & 1.73 & 0.05 & 0.02 & 3.56 & $\begin{array}{l}25.28 \\
(1.40)\end{array}$ & $\begin{array}{l}5057.00 \\
(3.703)\end{array}$ & $\begin{array}{l}95.50 \\
(9.77)\end{array}$ \\
\hline $\begin{array}{c}\text { Open cross } \\
\text { (emasculate } \\
\text { flower) }\end{array}$ & $\begin{array}{c}85.00 \\
(70.98)\end{array}$ & 2.84 & 0.23 & 0.13 & 37.76 & $\begin{array}{l}296.40 \\
(2.47)\end{array}$ & $\begin{array}{c}87720.00 \\
(4.94)\end{array}$ & $\begin{array}{l}94.50 \\
(9.72)\end{array}$ \\
\hline Controlled self & $\begin{array}{l}97.50 \\
(85.39)\end{array}$ & 2.93 & 0.25 & 0.14 & 42.08 & $\begin{array}{l}357.70 \\
(2.55)\end{array}$ & $\begin{array}{c}111600.0 \\
0 \\
(5.05)\end{array}$ & $\begin{array}{l}94.00 \\
(9.70)\end{array}$ \\
\hline $\begin{array}{l}\text { Controlled } \\
\text { cross }\end{array}$ & $\begin{array}{c}97.50 \\
(85.39)\end{array}$ & 2.97 & 0.25 & 0.14 & 44.48 & $\begin{array}{c}365.30 \\
(2.56)\end{array}$ & $\begin{array}{c}114000.0 \\
0 \\
(5.06)\end{array}$ & $\begin{array}{l}96.50 \\
(9.82)\end{array}$ \\
\hline CD & 13.33 & 0.05 & 0.01 & 0.006 & 3.19 & 0.01 & 0.03 & NS \\
\hline
\end{tabular}

*Figures in parentheses are ARC sine transformed values;

** Figures in parentheses are LOG transformed values;

***Figures in parentheses are Square Root Transformed values 
Fig.1 Morphological and reproductive parts of $O$. biennis
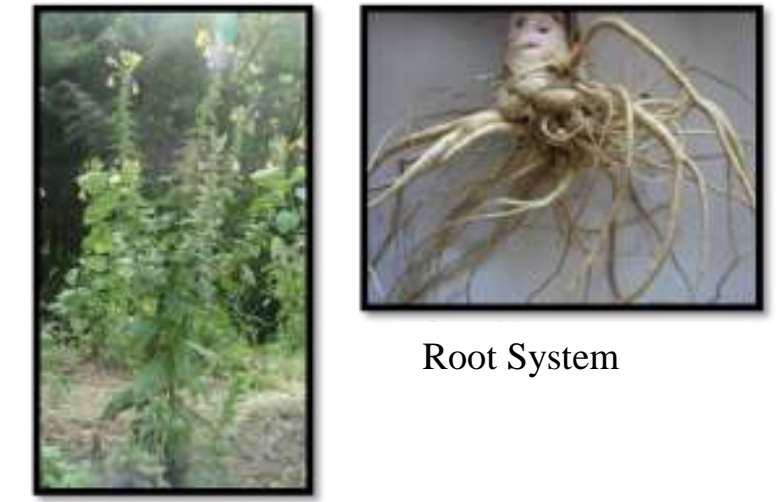

Root System

Oenothera biennis L. plant

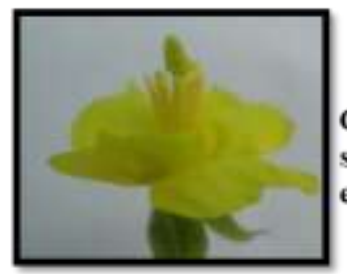

Compact, unreceptive stigma and stage of emasculation

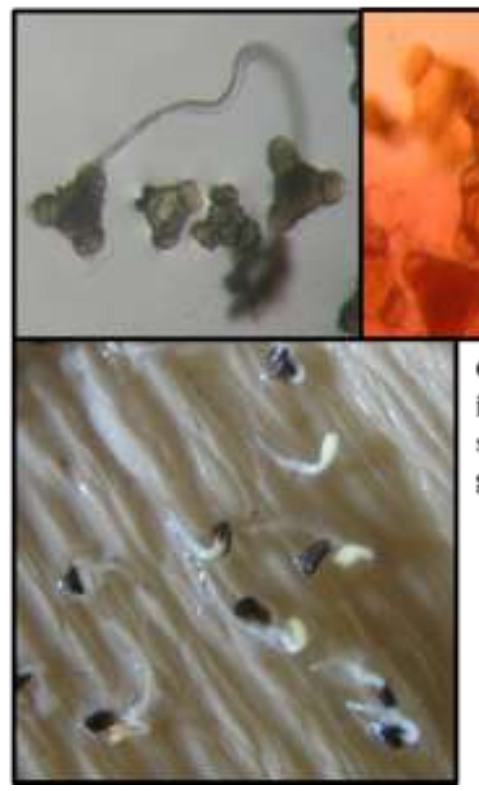

Germination of pollen in sucrose solution, on stigma and seed germination
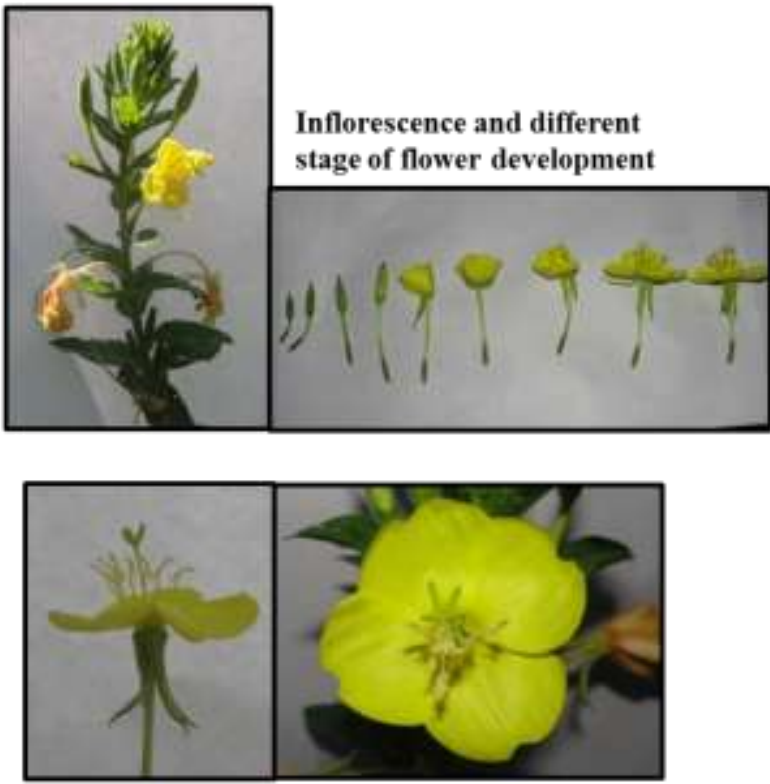

Dehisced sticky pollen, anthesis and radiating stigmatic lobes in the evening

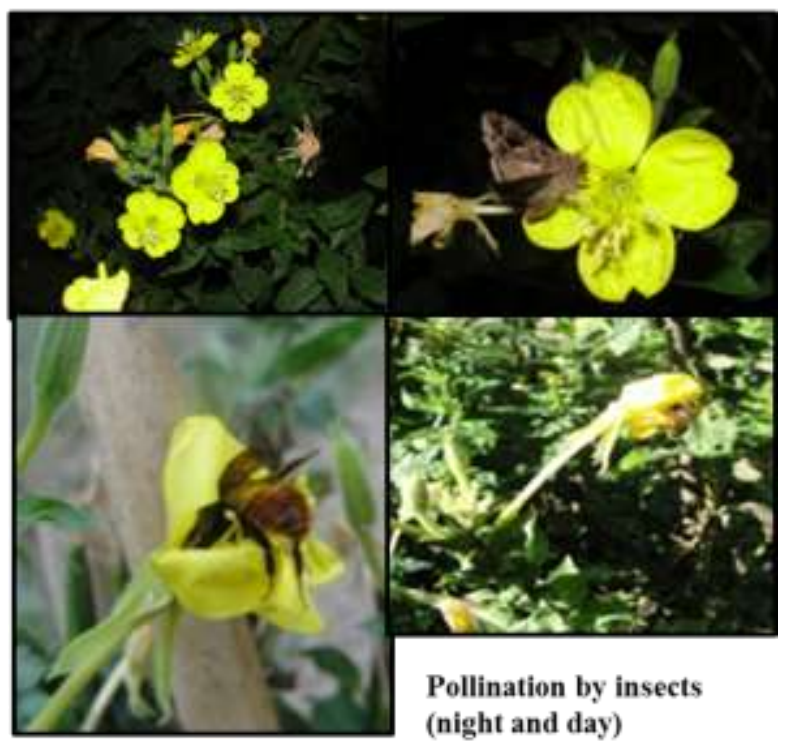

pollinated flowers) or their absence (due to emasculation in open cross-pollinated flowers) does not make any significant difference for fruit set in open and open cross-pollinated flowers and shows pollination by vector is the best for maximum fruit set in nature while some self-pollination is still possible in nature without vector as indicated by selfing (bagging). Inadequate pollens to fertilize

that the presence of anthers (in open- 
ovules in selfing due to position of anthers and stigma and absence of vectors could be the reason for low fruit set percentage (Table 7).

High fruit set (\%) in selfing is possible with human intervention. While Hall et al., (1988) and Steiner (1956) reported that the flowers are predominantly self-pollinated, but outcrossing does occur. Schooley (1965), Steiner (1961) and Levin et al., (1972) also mentioned the plant as naturally selfpollinating contrast to the present finding.

Insect vector visitation shows crossing is possible. This also supports the cross pollinating nature besides the position of anthers and stigma at and before anthesis. Hoff (1962) reported the relative lengths of anther and style as well as the amount of pollen produce influences the degree of outcrossing. Outcrossing was negatively correlated with the additions of self-pollen applied to the stigma. The germination percent indicated fertile seeds from every pollination treatment which represents cross and selfcompatible nature of the species (Table 7). More than 2 morphotypes were observed in the species.

\section{References}

Anonymous. 2009. Evening primrose oil (Oenothera biennis L.) [CAS No. 90028-66-3], Chemical Information Review Document, National Toxicology Program, National Institute of Health, US department of Health and Human Services, Research Triangle Park, NC. 2009.

Cavaliere, C., Rea, P., Lynch, M. E. and Blumenthal, M. 2009. Herbal supplement sales experience slight increase in 2008. Herbal Gram. 82: 5861.

Dement, W. A. and Raven, P. H. 1974. Pigments responsible for ultraviolet patterns in flowers of Oenothera (Onagraceae). Nature. 252 (5485): 705-706.

Deng, Y. C., Hua, H. M., Li, J. and Lapinskas, P. 2001. Studies on the cultivation and uses of evening primrose (Oenothera spp.) in China. Economic Botany. 55(1): 83-92.

Ghasemnezhad, A. 2007. Investigations on the effect of harvest methods and storage conditions on yield, quality and germination of evening primrose seeds. Ph.D. Dissertation (Agricultural sciences), Justus Liebig University, Giessen.

Gunstone, F. D. 1992. Gamma linolenic acidoccurrence and physical and chemical properties. Prog. Lipid Res. 32(2): 145-161.

Hall, I. V., Steiner, E., Threadgill, P. and Jones, R. W. 1988. The biology of Canadian weeds. 84. Oenothera biennis L. Canadian Journal of Plant Sciences. 68: 163-173.

Hoff, V. J. 1962. An analysis of outcrossing in certain complex heterozygous euoenotheras. I. Frequecncy of outcrossing. Am. J. Bot. 49: 715-721.

Horrobin, D. F. 1992. Nutritional and medical importance of gamma-linolenic acid. Progress in Lipid Research. 31(2): 163-94.

Hudson, B. J. F. 1984. Evening primrose (Oenothera spp.) oil and seed. J. A. O. C. S. 61(3): 540-543.

Immel, D. L. 2003. Common evening primrose. Plant Guide, formerly USDA, NRCS, National Plant Data Centre, University of California, Davis, California.

Levin, D. A., Howland, G. P. and Steiner, E. 1972. Protein polymorphism and genic heterozygosity in a population of the permanent translocation heterozygote, Oenothera biennis. Proc. Nat. Acad. Sci. 69(6): 1475-1477. 
Naik, T. C. P., Farooqi, A. A. and Joshi, S. S. (1999). Studies on floral biology of primrose (Oenothera lamarckiana L.). Indian Journal of Forestry. 22(3): 263 -265 .

Peschel, W., Dieckmann, W., Sonnenschein, M. and Plescher, A. 2007. High antioxidant potential of pressing residues from evening primrose in comparison to other oilseed cakes and plant antioxidant. Industrial Crops and Products, 25: 44-54.

Pullaiah, T. 2006. Encyclopedia of World Medicinal Plants. Regency Publications, New Delhi, Vol. III, p. 1429.

Ratnayake, W. M. N., Matthews, D. G. and Ackman, R. G. 1989. Triacylglycerols of evening primrose (Oenothera biennis) seed oil. J. A. O. C. S. 66(7): 966-968.
Riaz, A., Khan, R. A. and Ahmed, S. P. 2009. Assessment of anticoagulant effect of evening primrose oil. Pak. J. Pharm. Sci. 22(4): 355-359.

Schooley, J. B. 1965. The incompatibility mechanism of the biennis group I races of Oenothera. Genetics. 52: 145-152.

Steiner, E. 1956. New aspects of the balanced lethal mechanism in Oenothera. Genetics. 41: 486-500.

Steiner, E. 1961. Incompatibility studies in Oenothera. Zeitschrift fur Vererbungslehre. 92: 205-212.

Yunusova, S. G., Yunusov, M. S., Karimova, A. R., Minronov, V. F., Minzanova, S. G., Konovalov, A. I., Efremov, Y. Y., Denisenko, O. N. and Chernova, E. V. 2007. Lipids of Oenothera seeds from different habitats. Chemistry of Natural Compounds. 43(5): 525-528.

\section{How to cite this article:}

Usha Thakur, Bhupender Dutt, S. S. Sharma, Kulwant Rai Sharma and Nisha Thakur. 2019. Evening Primrose (Oenothera biennis L.): Morphology and Reproductive Biology. Int.J.Curr.Microbiol.App.Sci. 8(10): 1400-1409. doi: https://doi.org/10.20546/ijcmas.2019.810.164 